\title{
MENTAL HEALTH MORBIDITY IN INDUSTRIAL POPULATION OF SOUTH INDIA
}

Kiran Kumar P. K, S. Reshma, P. S. V. N. Sharma, Francis N. P. Monteiro, Sukesh

1. Associate Professor, Department of Psychiatry, A. J. Institute of Medical Sciences, Mangalore, India.

2. Assistant Professor, Department of Biochemistry, A. J. Institute of Medical Sciences, Mangalore, India.

3. Professor, Department of Psychiatry, Kasturba Medical College, Manipal, India.

4. Associate Professor, Department of Forensic Medicine \& Toxicology, A. J. Institute of Medical Sciences, Mangalore, India.

5. Associate Professor, Department of Pathology, Srinivas Institute of Medical Sciences and Research Centre, Mangalore, India.

\section{CORRESPONDING AUTHOR}

Dr. Francis N. P. Monteiro,

Associate Professor of Forensic Medicine \& Toxicology,

A.J. Institute of Medical Sciences,

Mangalore: 575004, India.

E-mail: drfrancis@rediffmail.com

Ph: 00919448327389.

ABSTRACT: BACKGROUND: The existing literature on mental health in an industrial population is very limited. This study will certainly add to the existing information on planning preventive and promotive measures in industrial population thereby safeguarding their health.

AIM: This cross sectional study was undertaken during the November and December month of 2001 in industrial population of a iron ore processing unit of Karnataka, India to study the epidemiology of mental health in industrial population and the associated risk factors. MATERIALS AND METHODS: This study was conducted in an Iron Ore processing company located in Chickamagalore District of Karnataka in the year 2001 (November and December) using Mini International Neuropsychiatric Interview Plus and Occupational Stress Index. 252 employees from 1537 population of Kuduremukh Township were selected as the study sample, which represents $16.4 \%$ of the total population of industrial workers. 235 were responders $(93.3 \%)$ and 17 were non-responders (6.7\%). Following a detailed interview with the selected industrial workers, diagnosis was made based on International Classification of Diseases-10, Classification of Mental and Behavioural Disorders: Diagnostic Criteria for Research. RESULTS: Majority of the study sample consists of males (95.7\%), Hindus (85.5\%), married persons (96.2\%), and originally from the state in which industry is located, i.e., Karnataka (96.2\%). In the present study current prevalence of depressive disorder is $6.8 \%$, dysthymia being $5.5 \%$. Lifetime prevalence of mood disorder is $17.8 \%$ major depression in $7.6 \%$. In the present study there were 59 cases without comorbid diagnoses Vs 26 cases with two or more comorbid diagnosis. Overall $31 \%$ cases had comorbid diagnosis. In the present study however no significant difference emerged between those with and without lifetimes or current psychiatric illness in variables such as sociodemographic characteristics, type of work perceived, work related problem and physical health problem. CONCLUSION: Overall the present study has found high rates of psychiatric (lifetime and current) in industrial workers in keeping with western and few recent Indian studies. But has failed to find a robust association between occupational stress and psychiatric morbidity.

KEYWORDS: Mental health; Stress; Comorbid; Depression 
INTRODUCTION: Over the last three decades awareness of potential mental effects of the work environment has grown among both academic health researchers and the lay public. Workers compensation claims for mental disabilities have proliferated since 1980, compelling most jurisdictions in Canada and the United Sates to consider broad issues involving psychological and emotional aspects of work. ${ }^{1}$ Industrial workers when compared to the rest of the population, have the added risk of physical, chemical, biological and other specific psychosocial factors of their occupational environment., 2,3 The prevalence rates of psychiatric morbidity in the Indian industrial population range from $14 \%$ to $37 \%$ and can be up to $74 \%$ in Western reports. ${ }^{4} \mathrm{~A}$ brief report on the problem status of psychiatric morbidity in industrial workers has prompted the authors to take up this research in detail, with a comparison with studies done elsewhere in India and abroad. ${ }^{5}$ The aims of this study were to study the epidemiology of mental health in industrial population of iron ore processing unit of Karnataka, India, and the associated risk factors.

MATERIALS AND METHODS: This cross sectional study was conducted in an Iron Ore processing company located in Chickamagalore District of Karnataka in the year 2001 (5 $5^{\text {th }}$ November to $24^{\text {th }}$ December). All the permanent employees enrolled by the company $(n=1537)$ were considered as the universe for the study and was drawn from an earlier study on Industrial workers in India. ${ }^{5}$ Sample size was calculated using EPI INFOR program by assuming an anticipated prevalence of overall psychiatric morbidity of $30 \%$ based on previous studies with confidence limit of $95 \%$ and relative precision of $20 \%$. Adequate sample for such conditions to be fulfilled was determined to be 202 . To provide for non response rate of $20 \%$ an additional 50 persons were included. Hence the final sample size was determined as 252 . These workers were derived into four groups according to their living quarter eligibility. Using random number tables sample was selected by proportions to the size of the groups $A, B, C$ and D. Hence category A yielded 95 subjects, category B yielded 1176 subjects, category C 197 subjects and category D 69 subjects. Study instruments included the Sociodemographic data proforma, Mini International Neuropsychiatric Interview plus and Occupational stress index.

The sociodemographic data proforma was specially constructed for this project. It yield information on age at joining, year of experience, nature or work, shift work, perceived shift problems, perceived interpersonal problems, job satisfaction.

The Mini International neuropsychiatric interview plus (MINI plus) is a short structured diagnostic interview developed jointly by psychiatrists and clinicians in the United States and Europe for generating DSM IV and ICD 10 psychiatric diagnosis. It was designed to meet the need for a short but accurate structured psychiatric interview for multicenter clinical trials and epidemiological studies and to be used as a first step in outcome tracking in non research clinical settings.

The occupational stress index purports to measure the extent of stress which employees perceive arising from various constituent and conditions of their job. However stress researchers have developed the scales which measure the stress arising exclusively from job roles. ${ }^{6}$ The tool may conveniently be administered to the employees of every level operating in context of industries or other non production organizations. However it is more suitable for the employees of supervisory level and above.

The scale consists of 46 items, each to be rated on the five point scale. Out of 43 items 28 are 'true-keyed' and rest 8 are 'false keyed'. The items relate to almost all relevant components of the job life which causes stress in some way or the other, such as role overload, 
role ambiguity, role conflict, group and political pressure, responsibility for persons, under participations, powerlessness, poor peer relations, intrincis impoverishment, low status, strenuous working condition and unprofitability. The reliability index as ascertained by splithalf (odd-even) method and Cronbach's alpha-coefficient for the scale as a whole was found to be 0.935 and 0.90 respectively. The validity of the occupational stress index was determined by computing coefficients of correlation between the scores on OSI and various measures of job attitudes and job behavior. The employees cores on the OSI is likely to positively correlate with the scores on the measures of such job related attitudinal and motivational and The correlation between the scores on Occupational Stress Index (OSI) and the measure of job anxiety was found to be $0.59(\mathrm{~N}=400)$.[7] The employee's scores on OSI have been found to be positively correlated with their scores on the measures of mental ill health, standardized by Srivastava et al. ${ }^{7}$ Since the questionnaire consist of both true keyed and false-keyed items two different patterns of scoring have to be adopted for two types of items. Norms have been prepared for the scores on occupational stress index as a whole as well as for its 12 subscales separately on a representative sample of 700 employees of different cadres operating in various production and non production organizations the scores were divided into three categories i.e. high, moderate, low following the principles of normal distribution.

The interview was conducted in the houses of the study subjects. With the help of the area map the houses of the randomly selected employee, were identified. The purpose of the visit was explained to the employer and to their family members and their cooperation was sought. After informed verbal consent was obtained, the randomly chosen respondent was administered MINI plus 2001 by the investigator. Care was taken to ensure privacy and confidentiality of the interview. Help of a psychiatry consultant sought to make sure that the interview process was carried out satisfactorily. The subjects were also given the Occupational Stress Index (OSI) questionnaire and were asked to fill and return them from next day. During the home visit if a house was found to be locked or if the respondent was not available three call back attempts were made to contact to him/her before considering him/her as non responder.

RESULTS: The present study was designed to elicit socio-demographic, lifetime and current psychiatric diagnostic and occupational stress data of the employees of an iron ore processing unit. Table 1 depicts the derivation of study sample. Table 2 depicts nature of work and perceived problems at work in the study sample. Majority belongs to B category $(75.3 \%)$ and minority to D category (5.1\%). Shift workers form the majority of workers (51.5\%). Shift problems are reported by almost half of the subjects (major 20.4\%), (minor 28.9\%), 37.9\% report some interpersonal problems at workplace and at least $5 \%$ experienced no job satisfaction.

Table 3 depicts the current primary axis 1 diagnosis in the study sample. The MINI plus can generate several diagnosis in an individual at any cross section of the time depending on the existing psychopathology. However there is an algorithm by which a single diagnosis may gain primacy. The table shows these primary diagnoses. Nicotine dependence constitute the most common current diagnosis and is seen in $10.2 \%$ of the population and nicotine abuse in $1.7 \%$. Alcohol dependence is seen in $2.1 \%$ of the population and alcohol abuse is seen in $2.1 \%$. Dysthymia is seen in 5.5\%. Major depressive episode in $0.9 \%$ and paranoid schizophrenia $0.9 \%$, $6.3 \%$ had pain disorder. Table 4 depicts the prevalence of all psychiatric disorders in the subjects. This includes current primary axis 1 diagnosis as well as current comorbid diagnoses. Nicotine dependence was the major diagnosis seen in 33 individuals (14\%) and nicotine abuse 
in $2.6 \%$ of the sample. 6 persons fulfilled the criteria for alcohol dependence $(2.6 \%)$ and 16 persons were alcohol abuse (6.8\%). Dysthymia was seen in 5.5\% of the sample. 7 persons had pain disorder $(7.2 \%)$ and $1.7 \%$ had panic disorder. Paranoid schizophrenia and major depressive disorder seen in $0.9 \%$ of the sample. In 85 subjects 117 numbers of diagnosis were made.

Table 5 depicts the distribution of comorbid diagnosis with current psychiatric diagnosis. Comorbidity occurred more frequently with Major depressive episode (100\%) having alcohol/nicotine dependence/abuse; Dysthymia (53.8\%) having alcohol and nicotine dependence/abuse, pain disorder and specific phobia, panic disorder (75\%) having alcohol or nicotine dependence or abuse and pain disorder, alcohol dependence or abuse (60\%) having major depression, nicotine dependence and hypochondriasis, Nicotine dependence (14\%) having alcohol dependence; and hypochondriasis (66\%) having alcohol and nicotine abuse/dependence. Overall the commonest comorbid diagnoses were alcohol dependence/abuse (12/30) and nicotine dependence/abuse(11/30). Table 6 depicts analysis of sociodemographic variable in persons with or without lifetime psychiatric diagnosis: There were no statistically significant differences between the two groups on sociodemographic variables. However it is noted that females, non-Hindus and married employees were having more lifetime psychiatric morbidity. $48.5 \%$ of the people with life time diagnosis had education related to technical courses compared to $10.6 \%$ with other education.

Table 7 depicts the analysis of nature of work and perceived problems at work in persons with and without lifetime psychiatric diagnosis: There is no statistically significant difference between two groups on these variables. However life time prevalence of psychiatric morbidity range between $41.7 \%$ (D group) and 58.8\% (B group) workers. Perceived problems at work place did not distinguish between the two groups. Table 8 depicts analysis of physical illness in persons with and without lifetime psychiatric diagnosis: There is no significant difference in the presence of physical illness between the two groups. Approximately half the sample in both the groups reports the presence of physical illness. Table 9 depicts the analysis of sociodemographic variables in persons with and without any current psychiatric diagnosis. Prevalence of current psychiatric morbidity is more in males (36.4\%), Hindus (36.8\%), unmarried (44.4\%) in employees belonging to Karnataka (37.4\%) but none of these variables between the two groups differ significantly. On the variable of educational status there is a statistically significant difference between the two groups with a lesser proportion of current psychiatric illness in the people with non technical courses (MA, Mcom, BA, Bcom) etc

Table 10 depicts analysis of nature of work and perceived problems at work in persons with and without current psychiatric diagnosis: There is no significant difference in the two groups on these variables. However current prevalence of psychiatric morbidity ranges between $20.0 \%$ (C group) to $43.8 \%$ (A group). Perceived problems at work place did not distinguish between the two groups. Table 11 depicts analysis of medical problems in persons with and without current psychiatric illness, which showed no statistical difference between the groups. Table 12 compares the sociodemographic data of responders and non-responders to the occupational stress index. Total responders were 185(78.7\%) and non-responders were 50 (21.3\%). Non-response rate was more in males non-Hindus, people from Karnataka but none of these finding were statistically significant. Response rates were uniform among married and unmarried. Table 13 depicts Analysis of nature of work and perceived problems at work in responders and non-responders of occupational index questionnaire. Response rate to the occupational stress index was $100 \%$ in group C and D workers. Non response rate in group A 
was $6 \%$ and in group B was $94 \%$ and shows statistically significant difference ( $\mathrm{p}=0.002$ ). Perceived problems did not distinguish between two groups. Table 14 depicts an analysis of presence or absence of physical problem in person who responded / did not respond to the occupational stress index questionnaire. There was no significant difference between the groups on this variable.

DISCUSSION: The present study is an epidemiological survey utilizing the recent improvements in mental disorder diagnostic criteria, standardized diagnostic interviews and survey research design. This study was conducted in an industrial township to estimate the prevalence of current and lifetime psychiatric disorders in the study population. For the present an adequate sample size was estimated on suggestions give by WHO. ${ }^{8}$ The sample was calculated by assuming a prevalence rate of $30 \%$ of all psychiatric morbidity in the community. This higher assumed prevalence was chosen because several previous Indian studies had not included sizable diagnostic groups such as psychoactive substances, neurotic disorders etc. Previous studies mainly used older classification system where as the DSMIV and ICD 10 classification used here have significantly more categories and subcategories. Previous studies predominantly relied on clinical interview for diagnosing where as the present study used a structured interview schedule, which is likely to make a more comprehensive evaluation of respondents. A relative precision of $20 \%$ and confidence limit of $95 \%$ was taken to estimate the sample size. Estimation of prevalence was done based on the whole sample excluding nonresponders. The sample frame was constructed on the basis of multistage random sampling to provide every employer in the population an equal chance of entering the study sample. The investigator stayed at the site during the period of data collection. All interviews were done in the houses of the respondents as is recommended in epidemiological field surveys. The completion rate in this study is $93.3 \%$ and a non-response rate of $6.7 \%$. The completion rate is much higher than that reported in the epidemiological catchment area study (68-79\%) and national comorbidity survey (82.6\%). ${ }^{9}$ This high response rate was possibly due to the active co-operation of the authorities and medical fraternity in the township.

Previous Indian studies have varied in the instrument used for case finding (such as symptom in others, key informant questionnaire, general health, somatic symptoms questionnaire, self reporting questionnaire and other screening questionnaire developed by instigators.) Ganguli used the Freeman anxiety Neurosis and psychosomatic test. ${ }^{2}$ Mittal et al. used Maudsley personality inventory, Indian Psychiatric Interview schedule, drug abuse monitoring system, Addiction severity index. ${ }^{10}$ Trivedi et al. used Cornell medical index as a screening for psychological and somatic symptoms. The definition of case has varied resulting in varying pick up and prevalence rates. ${ }^{11}$ Further more a diagnostic interview has been the routine clinical interview. This can lead to low pickup of disorders due to incomplete coverage. A structured or semi structured interview schedule is likely to elicit more complete information and a true picture of prevalence of disorders in the community. All third generation epidemiological studies have used such standardized and validated instruments such as Diagnostic Interview Schedule (DIS). The present study used MINI plus 2001. This is a relatively recent instrument, which generates lifetime and current DSMIV and ICD10 diagnosis. Although it does not generate personality disorder diagnosis, brerity is its advantage. In the absence of training in India for SCAN, Mini plus was chosen and used after training and under the supervision of a psychiatry consultant. An occupational stress index questionnaire was used to measure the extent of the stress, which employees perceive arising from various constituents 
and conditions of the job. Stress researchers have developed the scales, which measure the stress arising from job roles. ${ }^{12}$ The tool may continuously administered to the employees of every level operating in context of industries or other non-production organizations. However it would prove more suitable for the employees of supervisory level and above. There are definite evidences to suggest a causal relationship between work and mental illness. Gnam reported list of mental disorders which plausibly or possibly have work related causation. Hence the need to look for associations between stress and psychiatric morbidity. ${ }^{1}$

252 employees from 1537 population of Kuduremukh Township were selected as the study sample, which represents $16.4 \%$ of the total population of industrial workers. 235 were responders $(93.3 \%)$ and 17 were non-responders (6.7\%). The present study used a stratified random sampling strategy to include proportionate number of individuals from the four socioeconomic strata in the study population. The nature of the population was such that the majority belong to category B (third lowest socioeconomic category) where as the minority belonged to category D (highest socioeconomic category) Although the income status of the four categories suggest that in actual terms all the workers would belong to middle to upper class, they are differentiated in terms of the nature of their work. In the present study current prevalence of depressive disorder is $6.8 \%$, dysthymia being $5.5 \%$. Lifetime prevalence of mood disorder is $17.8 \%$ major depression in $7.6 \%$. Ganguli et al. reported neurotic depression in $3.4 \%$ of workers, Gautam and Bairwa found neurotic depression in 57.89\%, Sethi et al. reported 19.4/1000.2,13,14 Trivedi et al. reported prevalence of affective disorder as $8.3 \% .{ }^{15}$ Alderete reported lifetime prevalence of affective disorder as 5.7\%.6 The estimated prevalence in Indian studies is $12.3 / 1000,34 / 1000$ whereas epidemiological catchment area study reports lifetime prevalence of major depressive episode $5.8 \%$ and dysthymia 3.3\%.11,16 In India studies estimating only depression showed a prevalence ranging from 1.26 to $67.0 / 1000.14,17,18,19$ Higher rates are seen in prevalence rates of depressive disorders in the present study are in keeping with international general epidemiological studies and more recent industrial population studies. Older Indian studies which used first and second generation methodology almost invariably yielded less caseness rates. Depression has been linked to industrial stress and this may explain higher prevalence. ${ }^{1}$

In the present study there were 59 cases without comorbid diagnoses Vs 26 cases with two or more comorbid diagnosis. Of these 4 had three diagnoses. Overall 31\% cases had comorbid diagnosis. Robin et al. reported $60 \%$ comorbidity in one month prevalence study. ${ }^{20}$ Kumar reported $65.2 \%$ comorbidity. ${ }^{21}$ Kessler et al reported $79 \%$ comorbidity with lifetime disorders. ${ }^{9}$ In contrast to these studies comorbidity reported here appears to be less. And majority and comorbidity seems to be alcohol and nicotine related. The issue of comorbidity is complex and not yet clearly understood to an extent generation of comorbid diagnosis depends on the algorithm or the instrument used. It is possible that DIS and SCAN may generate more comorbid diagnosis than MINI plus. ${ }^{20,21}$ Mittal et al. reported that psychiatric morbidity was significantly higher among single (unmarried and widower), living in nuclear family, Muslims and Sikhs, having job stress and financial burden. ${ }^{10}$ There was no significant difference with age, education, family size, percapita income. Trivedi et al. reported that psychotic disorders were significantly more prevalent in the age group of about 30 years, in high literacy group, nuclear family. ${ }^{15}$ Also prevalence was more in married and in housewives. Some of the associations reported in this area are likely to be highly sample and industry specific and may not generalized. 
In the present study however no significant difference emerged between those with and without lifetimes or current psychiatric illness in variables such as sociodemographic characteristics, type of work perceived work related problem and physical health problem except a significant difference in educational status between those with and without current psychiatric disorder there being proportionately less current psychiatric morbidity in persons from other education back grounds (BA, MA, B.Com, M.Com., etc). These persons were employed not in the primary industrial activities but as administrative and ancillary staff. Perceived stress among the employees was measured using the Occupational stress index. ${ }^{7}$ The respondents were allowed to complete the questionnaire at leisure. Participation in the study was voluntary. Overall Response rate was 78.7\%. Response rate in D and C group of workers i.e., managers, supervisors etc., was $100 \%$. Srivastava in the manual reported that the tool may be administered to the employees of every level operating in the context of industries. ${ }^{7}$ However it would prove more suitable for employees of suspervisory level and above. $26 \%$ of the responders had moderate to severe stress. Stress levels were more in persons with lifetime psychiatric diagnosis as well as current lifetime diagnosis but they were statistically not significant. Perceived occupational stress is related to psychiatric morbidity. ${ }^{22}$ This is not seen in directly in the present study. However it is interesting to note that when the 185 persons who responded to the OSIQ were compared with the 50 persons who did not respond a significance difference occurred. In that all category $C$ and $D$ workers were responded where as several category A and B workers were non responders. There was also significantly higher current psychiatric morbidity amongst non-responders. Amongst the responders there is no correlation between stress level and any of the variables under study except other educational back ground that are least stressed. The stress level of non-responders on OSIQ who also have higher representation of lower socioeconomic status household and higher psychiatric morbidity is not known. In this situation it is difficult in this study to comment on the relation of occupational stress to psychiatric morbidity noted by previous workers. It is however clear that workers not directly involved in the industrial process seem to experience less stress and have less psychiatric disorder.

Kar et al. reported that compared to workers managers had more psychiatric morbidity. This is not found in the present study. ${ }^{23}$ An explanation for this each of associations between stress and psychiatric morbidity in the present study (apart from the non responders) may be that OSIQ was filled in the population subsequent to the interview and investigator retrieved the forms often weeks after the clinical interview. This method may have some way influenced reports of stress. Overall the present study has found high rates of psychiatric (lifetime and current) in industrial workers in keeping with western and few recent Indian studies. But has failed to find a robust association between occupational stress and psychiatric morbidity. The implications of the finding of the high psychiatric morbidity amongst these industrial workers on labor market, worker health and productivity, ceremony and healthcare delivery planning would be of great importance.

\section{REFERENCES:}

1. Sullivan T. Injury and the new world of work. Vancouver: UBC Press; 2000.

2. Ganguli HC. Prevalence of psychological disorders in an Indian industrial population Part I, II and III. Indian J Med Res 1968; 56: 754-76. 
3. Bhaskaran K, Seth RC, Yadav SN. Migration and mental ill health in industry. Indian J Psychiat 1970; 12: 102-16.

4. Kar N, Dutta S, Patnaik S. Mental health in an Indian industrial population: Screening for psychiatric symptoms. Indian Journal of Occupational and Environmental Medicine 2002; 6 : 86-8.

5. Kumar KPK, Jayaprakash K, Monteiro FNP, Bhagavath P. Psychiatric Morbidity in Industrial Workers of South India. Journal of clinical and diagnostic Research 2011; 5(5): 921-925.

6. Alderete E, Vega WA, Kolody B, Aguilar-Gaxiola S. Lifetime Prevalence of and Risk Factors for Psychiatric Disorders among Mexican Migrant Farmworkers in California. Am J Public Health 2000; 90(4): 608-614.

7. Srivastava AK, Singh AP. Construction and Standardization of Occupational Stress Index: A pilot study. Indian J Clin Psychol 1981; 8: 133-136.

8. Lwanga SK, Lemeshaw S. Sample size determination in health studies: A practical manual. Geneva: WHO; 1991.

9. Kessler R, Sonnega A, Bromet E et al. Posttraumatic stress disorder in the National Comorbidity Survey. Arch Gen Psychiat 1995; 52: 1048-1060.

10. Mittal A, Verma KV, Solanki RK, Singhal AK, Jain A. A study of psychiatric morbidity in Railway workshop workers. Ind Psychiat J 2000; 9: 1-11.

11. Reddy MV, Chandrashekar CR. Prevalence of mental and behavioral disorders in India: A meta-analysis. Indian J Psychiat 1998; 40: 149-57.

12. Rizzo, J., House, R., and Lirtzman, S. Role conflict and ambiguity in complex organizations. Administrative Science Quarterly, 1970, 15, 150-163.

13. Gautam S, Bairwa CP. A study of psychiatric morbidity among industrial workers. [MD Dissertation] Jaipur: Rajasthan University; 1991.

14. Sethi BB, Gupta SC, Kumari P. A psychiatric survey of 500 rural families. Indian J Psychiat; 14: 183-196.

15. Trivedi A, Saihgal SK, Mahto J, Sahu SN. Psychiatric morbidity in Steel Township: An edpdemiological survey. Ind Psychiat J 1990; 3: 57-62.

16. Ganguli HC. Epidemiological findings on prevalence of mental disorders in India: Indian Journal of Psychiatry. 2000, 42(1) 14-20.

17. Dubey KC. A study of prevalence and biosocial variables in mental illness in rural and urban community in Uttar Pradesh. Acta psychiat Scand 1970; 46: 327-359.

18. Verghese A, Beig A, Senseman LA, Rao PSS, Benjamin V. A social and psychiatric study of a representative group of families in Vellore town. Indian J Med Res 1973; 61: 618.

19. Nandi DN, Ajmany S, Ganguli H et al. Psychiatric disorders in rural community study. Indian J Psychiat 1975; 17: 87.

20. Robin LN, Helzer JE, Weissman MM et al. Lifetime prevalence of specific psychiatric disorders in three states. Arch general psychiatry. 1984:41:949-958.

21. Kumar A. Psychiatric morbidity in a rural, low socioeconomic status population: An epidemiological field survey. A Dissertation submitted to MAHE: July 2000.

22. Rao GP, Moinuddin K, Sai PG, Sarma E, Sarma A, Rao PS. A study of stress and psychiatric morbidity in the central industrial security force. Indian Journal of Psychological Medicine 2008;30:39-47.

23. Kar N, Dutta S, Patnik S, Mishra B, Singh P.A comparative study of psychiatric morbidity among managers and workers of a fertilizer factory. Industrial psychiatry journal 2001 April. Vol. 10.1-18. 
Table [1]: Derivation of study sample

\begin{tabular}{|l|c|c|c|}
\hline $\begin{array}{c}\text { Stratification of study } \\
\text { population according to } \\
\text { living quarter availability }\end{array}$ & $\begin{array}{c}\text { Total Number of } \\
\text { employees in each } \\
\text { category N=1537 }\end{array}$ & $\begin{array}{c}\text { Required sample } \\
\text { size N=252 } \\
(16.4 \%)\end{array}$ & $\begin{array}{c}\text { Study population } \\
\text { N=235(93.3\%) }\end{array}$ \\
\hline A category & 95 & 16 & $16(100 \%)$ \\
\hline B category & 1176 & 192 & $177(92.2 \%)$ \\
\hline C category & 197 & 32 & $30(93.8 \%)$ \\
\hline D category & 69 & 12 & $12(100 \%)$ \\
\hline
\end{tabular}

Table [2] : Nature of work and perceived problems at work in study sample

\begin{tabular}{|l|c|c|}
\hline \multicolumn{1}{|c|}{ Variable } & Frequency (N) & Percentage (\%) \\
\hline Category of workers according to the basic & & \\
salary & 16 & 6.8 \\
A category Rs. 3,810 - 5,030 & 177 & 75.3 \\
B category Rs. 5,070 - 9,950 & 30 & 12.8 \\
C category Rs. 10,100 - 16,950 & 12 & 5.1 \\
D category Rs. 17,200 - 27,050 & & \\
\hline Shift (Time in hours) & 93 & 39.6 \\
ABC(6-2,2-10,10-6) & 114 & 48.5 \\
GEN(8-5) & 28 & 11.9 \\
AB(6-2,2-10) & 48 & 20.4 \\
\hline Shift problems & 68 & 28.9 \\
Major problems & 61 & 26.0 \\
Minor problems & 58 & 24.7 \\
Not applicable & & \\
No problems & 11 & 04.7 \\
\hline Interpersonal problems in work place & 78 & 33.2 \\
Major problems & 145 & 61.7 \\
Minor problems & 128 & \\
No problem & 96 & 54.5 \\
\hline Job satisfaction & 11 & 40.9 \\
Full satisfaction & & 04.7 \\
Satisfied & & \\
Not satisfied & & \\
\hline & & \\
\hline
\end{tabular}

Table [3]: Current primary axis 1 diagnosis in study sample generated by MINI - Plus.

\begin{tabular}{|l|c|c|c|c|c|}
\hline \multicolumn{1}{|c|}{ Disorder } & DSM 4 & ICD-10 & $\begin{array}{c}\text { Current } \\
\text { diagnosis } \\
\text { N=85 }\end{array}$ & \% & 95\% C.I. \\
\hline Major depressive episode (MDE) & 296. & F32 & 2 & 0.9 & $0-2.1$ \\
\hline $\begin{array}{l}\text { MDE due to a general medical } \\
\text { condition }\end{array}$ & 293.83 & F06 & & & \\
\hline Dysthymia & 300.4 & F34.1 & 13 & 5.5 & $2.6-8.4$ \\
\hline
\end{tabular}


ORIGINAL ARTICLE

\begin{tabular}{|l|c|c|c|c|c|}
\hline Panic disorder & 300. & F41.0 & 4 & 1.7 & $0-3.4$ \\
\hline Social Phobia & 300.23 & F40.1 & 1 & 0.4 & $0-1.2$ \\
\hline Specific phobia & 300.29 & F40.2 & 2 & 0.9 & $0-2.1$ \\
\hline Alcohol dependence syndrome & 303.90 & F10.2 & 5 & 2.1 & $0.3-3.9$ \\
\hline Alcohol abuse & 305.00 & F10.1 & 5 & 2.1 & $0.3-3.9$ \\
\hline $\begin{array}{l}\text { Substance dependence } \\
\text { syndrome (nicotine) }\end{array}$ & 305.10 & F17.2 & 24 & 10.2 & $6.3-14.1$ \\
\hline Substance abuse (nicotine) & 305.90 & F17.1 & 4 & 1.7 & $0-3.4$ \\
\hline Paranoid schizophrenia & 295.30 & F20 & 2 & 0.9 & $0-2.1$ \\
\hline $\begin{array}{l}\text { Psychotic disorder due to } \\
\text { general medical condition }\end{array}$ & 293. & F06.2 & & & \\
\hline Psychotic disorder NOS & 298.9 & F29 & 2 & 0.9 & $0-2.1$ \\
\hline Hypochondriasis & 300.7 & F45.2 & 3 & 1.3 & $0-2.8$ \\
\hline Plain disorder & 307. & F45.4 & 15 & 6.3 & $3.2-9.4$ \\
\hline Adjustment disorder & 309. & F43 & 2 & 0.9 & $0-2.1$ \\
\hline Mixed anxiety and depression & & F41.3 & 1 & 0.4 & $0-1.2$ \\
\hline $\begin{array}{l}\text { Substance induced mood } \\
\text { disorder }\end{array}$ & 291.8 & & & & \\
\hline $\begin{array}{l}\text { Substance induced psychotic } \\
\text { disorder }\end{array}$ & 291. & & & & \\
\hline
\end{tabular}

Table [4]: Current prevalence of all psychiatric diagnosis in study sample

\begin{tabular}{|l|c|c|c|c|c|}
\hline \multicolumn{1}{|c|}{ Disorder } & DSM 4 & ICD-10 & $\begin{array}{c}\text { Current } \\
\text { diagnosis } \\
\text { N=85 }\end{array}$ & \% & 95\% C.I. \\
\hline Major depressive episode (MDE) & 296. & F32 & 2 & 0.9 & $0-2.1$ \\
\hline $\begin{array}{l}\text { MDE due to a general medical } \\
\text { condition }\end{array}$ & 293.83 & F06 & & & \\
\hline Dysthymia & 300.4 & F34.1 & 13 & 5.5 & $2.6-8.4$ \\
\hline Panic disorder & 300. & F41.0 & 4 & 1.7 & $0-3.4$ \\
\hline Social Phobia & 300.23 & F40.1 & 1 & 0.4 & $0-1.2$ \\
\hline Specific phobia & 300.29 & F40.2 & 4 & 1.7 & $0-3.4$ \\
\hline Alcohol dependence syndrome & 303.90 & F10.2 & 6 & 2.6 & $0.6-4.6$ \\
\hline Alcohol abuse & 305.00 & F10.1 & 16 & 6.8 & $3.6-10.0$ \\
\hline $\begin{array}{l}\text { Substance dependence } \\
\text { syndrome (nicotine) }\end{array}$ & 305.10 & F17.2 & 33 & 14 & $9.6-18.4$ \\
\hline Substance abuse (nicotine) & 305.90 & F17.1 & 6 & 2.6 & $0.6-4.6$ \\
\hline Paranoid schizophrenia & 295.30 & F20 & 2 & 0.9 & $0-2.1$ \\
\hline $\begin{array}{l}\text { Psychotic disorder due to } \\
\text { general medical condition }\end{array}$ & 293. & F06.2 & & & \\
\hline Psychotic disorder NOS & 298.9 & F29 & 2 & 0.9 & $0-2.1$ \\
\hline Hypochondriasis & 300.7 & F45.2 & 4 & 1.7 & $0-3.4$ \\
\hline Plain disorder & 307. & F45.4 & 17 & 7.2 & $3.9-10.5$ \\
\hline Adjustment disorder & 309. & F43 & 2 & 0.9 & $0-2.1$ \\
\hline
\end{tabular}


ORIGINAL ARTICLE

\begin{tabular}{|c|c|c|c|c|c|}
\hline Mixed anxiety and depression & & F41.3 & 1 & 0.4 & $0-1.2$ \\
\hline $\begin{array}{l}\text { Substance induced mood } \\
\text { disorder }\end{array}$ & 291.8 & & & & \\
\hline $\begin{array}{l}\text { Substance induced psychotic } \\
\text { disorder }\end{array}$ & 291. & & 1 & 0.4 & $0-1.2$ \\
\hline & & \multicolumn{2}{|c|}{ Total diagnosis 115} & & \\
\hline
\end{tabular}

Table [5] : Distribution of comorbid diagnosis in persons with current primary diagnosis

\begin{tabular}{|c|c|c|c|c|c|c|c|c|}
\hline $\begin{array}{l}\text { Comorbid } \\
\text { diagnosis } \Rightarrow \\
\text { Current } \\
\text { primary } \\
\text { diagnosis } \square\end{array}$ & $\begin{array}{l}\text { Major } \\
\text { depre- } \\
\text { ssive } \\
\text { episode }\end{array}$ & $\begin{array}{l}\text { Panic } \\
\text { dis- } \\
\text { order }\end{array}$ & $\begin{array}{l}\text { Specific } \\
\text { phobia }\end{array}$ & $\begin{array}{l}\text { Alcohol } \\
\text { depend- } \\
\text { ence or } \\
\text { abuse }\end{array}$ & $\begin{array}{l}\text { Drug } \\
\text { depen- } \\
\text { dence } \\
\text { or } \\
\text { abuse }\end{array}$ & $\begin{array}{l}\text { Psycho- } \\
\text { tic dis- } \\
\text { order }\end{array}$ & $\begin{array}{l}\text { Pain } \\
\text { dis- } \\
\text { order }\end{array}$ & $\begin{array}{l}\text { Total } \\
\text { comorbid } \\
\text { diagnosis }\end{array}$ \\
\hline $\begin{array}{l}\text { Major } \\
\text { depressive } \\
\text { Episode } \\
(\mathrm{n}=2)\end{array}$ & & & & $1(50)$ & $1(50)$ & & & $2(100 \%)$ \\
\hline $\begin{array}{l}\text { Dysthymia } \\
(\mathrm{n}=13)\end{array}$ & & & $1(14.3)$ & $3(42.9)$ & $2(28.6)$ & & $1(14.3)$ & $7(54 \%)$ \\
\hline $\begin{array}{l}\text { Panic } \\
\text { disorder } \\
(n=4)\end{array}$ & & & & $1(33.3)$ & $1(33.3)$ & & $1(33.3)$ & $3(75 \%)$ \\
\hline $\begin{array}{l}\text { Social phobia } \\
(n=1)\end{array}$ & & & $1(100)$ & & & & & $1(100 \%)$ \\
\hline $\begin{array}{l}\text { Alcohol } \\
\text { dependence } \\
\text { and abuse } \\
(n=10)\end{array}$ & $1(14.3)$ & & & & $4(57.1)$ & $1(14.3)$ & & $6(60 \%)$ \\
\hline $\begin{array}{l}\text { Drug } \\
\text { Dependence } \\
\text { or abuse } \\
\text { (nicotine) } \\
(\mathrm{n}=28)\end{array}$ & & & & $4(100)$ & & & & $4(14 \%)$ \\
\hline $\begin{array}{l}\text { Hypochondri } \\
\text { asis }(n=3)\end{array}$ & & & & $1(50)$ & $1(50)$ & & & $2(67 \%)$ \\
\hline $\begin{array}{l}\text { Pain } \\
\text { disorder } \\
(n=15)\end{array}$ & & & & $2(40 \%)$ & $2(40 \%)$ & & $1(20 \%)$ & $5(33 \%)$ \\
\hline \multicolumn{8}{|c|}{ Grand total comorbid diagnosis } & 30 \\
\hline
\end{tabular}


Table [6] : Analysis of sociodemographic variables in persons with and without any lifetime psychiatric diagnosis

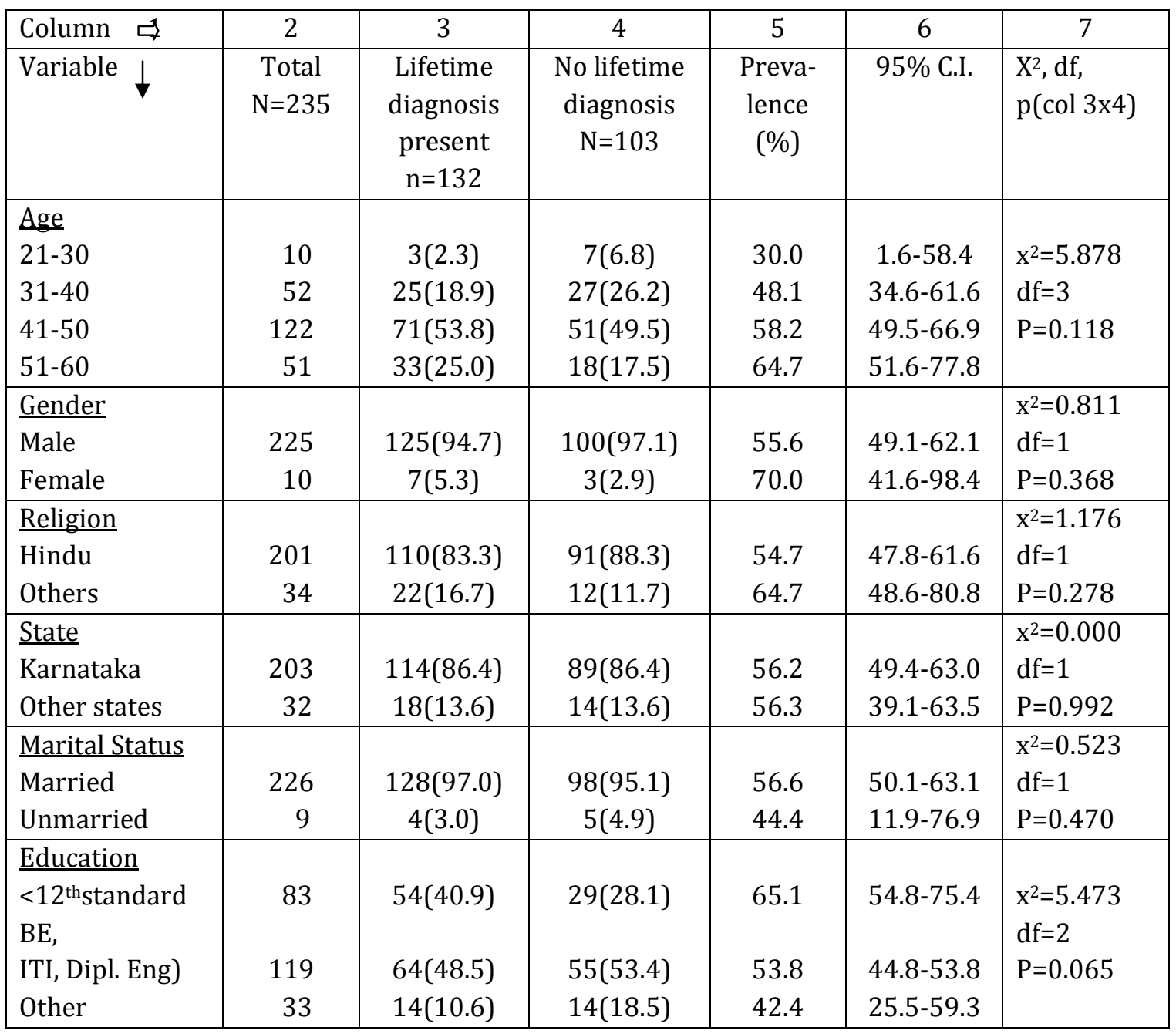

Table [7]: Analysis of nature of work and perceived problems at work in persons with and without psychiatric diagnosis

\begin{tabular}{|c|c|c|c|c|c|c|}
\hline Column 1 & 2 & 3 & 4 & 5 & 6 & 7 \\
\hline Variable $\downarrow$ & $\begin{array}{c}\text { Total } \\
\mathrm{N}=235\end{array}$ & $\begin{array}{c}\text { Lifetime } \\
\text { psychiatry } \\
\text { cases } \\
\mathrm{N}=132 \\
\text { (except } \\
\mathrm{N}=104 \text { ) }\end{array}$ & $\begin{array}{c}\text { No lifetime } \\
\text { diagnosis } \\
\mathrm{N}=103 \\
\text { (except } \\
\mathrm{N}=70 \text { ) }\end{array}$ & $\begin{array}{c}\text { Preva- } \\
\text { lence } \\
(\%)\end{array}$ & 95\% C.I. & $\begin{array}{l}\mathrm{X}^{2}, \mathrm{df}, \mathrm{P} \\
(\operatorname{col} 3 \mathrm{x} 4)\end{array}$ \\
\hline $\begin{array}{l}\text { Category of workers } \\
\text { according to the basic salary }\end{array}$ & & & & & & \\
\hline A category Rs.3,810-5,030 & 16 & $7(5.3)$ & $8(7.8)$ & 43.8 & $19.5-68.1$ & $x^{2}=2.607$ \\
\hline B category Rs.5,070-9,950 & 177 & $104(78.8)$ & $63(61.1)$ & 58.8 & $51.5-66.1$ & $\mathrm{df}=3$ \\
\hline
\end{tabular}


ORIGINAL ARTICLE

\begin{tabular}{|c|c|c|c|c|c|c|}
\hline C categoryRs.10,100-16,950 & 30 & $16(12.1)$ & $14(13.5)$ & 53.3 & $35.4-71.2$ & $\mathrm{P}=0.456$ \\
\hline D categoryRs. $17,200-27,050$ & 12 & $5(3.8)$ & $7(6.8)$ & 41.7 & $13.8-69.6$ & \\
\hline Shift & & & & & & $x^{2}=0.609$ \\
\hline $\mathrm{ABC} / \mathrm{AB}$ & 121 & $65(49.2)$ & $56(54.3)$ & 53.7 & $44.8-62.6$ & $\mathrm{df}=2$ \\
\hline GEN & 114 & $67(50.8)$ & $47(45.6)$ & 58.8 & $49.8-67.8$ & $\mathrm{P}=0.737$ \\
\hline Shift problems $(\mathrm{N}=174)$ & & & & & & $x^{2}=2.342$ \\
\hline Present & $116^{*}$ & $74^{*}(71.2)$ & $42(60.0)$ & 63.8 & $55.1-72.5$ & $\mathrm{df}=1$ \\
\hline Absent & $58 *$ & $30 *(28.8)$ & $28(40.0)$ & 51.7 & $38.8-64.6$ & $\mathrm{P}=0.126$ \\
\hline Interpersonal problems & & & & & & $x^{2}=2.170$ \\
\hline Present & 90 & $56(42.4)$ & $34(33.0)$ & 62.2 & $52.2-72.2$ & $\mathrm{df}=1$ \\
\hline Absent & 145 & $76(57.6)$ & $69(66.9)$ & 52.4 & $44.3-60.5$ & $\mathrm{P}=0.141$ \\
\hline Iob satisfaction & & & & & & $x^{2}=1.132$ \\
\hline Full satisfaction & 128 & $68(51.5)$ & $60(58.2)$ & 53.1 & $44.5-61.7$ & $\mathrm{df}=2$ \\
\hline Satisfied / NS & 107 & $64(48.5)$ & $43(41.7)$ & 59.8 & $50.5-69.1$ & $\mathrm{P}=0.568$ \\
\hline
\end{tabular}

Table [8]: Analysis of medical problems in persons with lifetime psychiatric diagnosis in study sample

\begin{tabular}{|c|c|c|c|c|c|c|}
\hline Column 1 & 2 & 3 & 4 & 5 & 6 & 7 \\
\hline Medical problems & $\begin{array}{c}\text { Frequencie } \\
\mathrm{s}(\mathrm{N}=235)\end{array}$ & $\begin{array}{c}\text { Lifetime } \\
\text { psychiatry } \\
\text { cases } \\
(\mathrm{N}=132)\end{array}$ & $\begin{array}{c}\text { No lifetime } \\
\text { diagnosis } \\
\mathrm{N}=103\end{array}$ & $\begin{array}{c}\text { Prevalence } \\
\text { (\%) }\end{array}$ & $95 \%$ C.I. & $\mathrm{X}^{2}, \mathrm{df}, \mathrm{P}$ \\
\hline Present & 72 & $43(32.6)$ & $29(28.2)$ & 59.7 & $48.4-61.0$ & \multirow{2}{*}{$\begin{array}{l}X^{2}=0.532 \\
d f=1 \\
p=0.466\end{array}$} \\
\hline Absent & 163 & $89(67.4)$ & $74(71.8)$ & 54.6 & $46.9-62.2$ & \\
\hline
\end{tabular}

Table [9]: Analysis of sociodemographic variables in persons with and without any current psychiatric diagnosis.

\begin{tabular}{|c|c|c|c|c|c|c|}
\hline Column $\Rightarrow 1$ & 2 & 3 & 4 & 5 & 6 & 7 \\
\hline Variable $\downarrow$ & $\begin{array}{c}\text { Total } \\
\mathrm{N}=235\end{array}$ & $\begin{array}{c}\text { Current } \\
\text { Psychiatry } \\
\text { cases } \\
\mathrm{N}=85\end{array}$ & $\begin{array}{c}\text { No current } \\
\text { diagnosis } \\
\mathrm{N}=150\end{array}$ & $\begin{array}{c}\text { Prevalence } \\
\text { (\%) }\end{array}$ & 95\% C.I. & $\begin{array}{l}X^{2}, \quad d f, \quad P \\
(\operatorname{col} 3 x 4)\end{array}$ \\
\hline Age & & & & & & \\
\hline $21-30$ & 10 & $3(3.5)$ & $7(4.7)$ & 30.0 & $1.6-58.4$ & $X^{2}=1.555$ \\
\hline $31-40$ & 52 & $17(20.0)$ & $35(23.3)$ & 32.7 & $24.4-41.0$ & $\mathrm{df}=3$ \\
\hline $41-50$ & 122 & $43(50.6)$ & $79(52.7)$ & 35.2 & & $\mathrm{p}=0.670$ \\
\hline $51-60$ & 51 & $22(25.9)$ & $29(19.3)$ & 43.1 & & \\
\hline Gender & & & & & & $\mathrm{X}^{2}=0.172$ \\
\hline Male & 225 & $82(96.5)$ & $143(95.3)$ & 36.4 & $30.1-42.7$ & $\mathrm{df}=1$ \\
\hline Female & 10 & $3(3.5)$ & $7(4.7)$ & 30.0 & $01.6-58.4$ & $p=0.678$ \\
\hline$\frac{\text { Religion }}{\text { Hindu }}$ & 201 & $74(87.0)$ & $127(84.7)$ & 36.8 & $30.1-43.5$ & $\begin{array}{l}\mathrm{X}^{2}=0.251 \\
\mathrm{df}=1\end{array}$ \\
\hline
\end{tabular}


ORIGINAL ARTICLE

\begin{tabular}{|l|r|c|c|c|c|l|}
\hline Other religion & 34 & $11(13.0)$ & $23(15.3)$ & 32.4 & $16.7-48.1$ & $\mathrm{p}=0.616$ \\
\hline State & & & & & & $\mathrm{X}^{2}=1.039$ \\
Karnataka & 203 & $76(89.4)$ & $127(84.7)$ & 37.4 & $30.7-44.1$ & $\mathrm{df}=1$ \\
Other states & 32 & $9(10.6)$ & $23(15.3)$ & 28.1 & $12.5-43.7$ & $\mathrm{p}=0.308$ \\
\hline Marital Status & & & & & & $\mathrm{X}^{2}=0.278$ \\
Married & 226 & $81(95.3)$ & $145(96.7)$ & 35.8 & $29.5-42.1$ & $\mathrm{df}=1$ \\
Unmarried & 9 & $4(4.7)$ & $5(3.3)$ & 44.4 & $11.9-76.9$ & $\mathrm{p}=0.598$ \\
\hline Education & & & & & & $\mathrm{X}^{2}=9.676$ \\
<12 ${ }^{\text {th std }}$ & 83 & $38(44.7)$ & $45(30.0)$ & 45.8 & $35.1-56.5$ & $\mathrm{df}=2$ \\
ITI, Diploma & 119 & $42(49.4)$ & $77(51.3)$ & 35.3 & $26.7-43.9$ & $\mathrm{p}=0.008$ \\
Engineering, BE & & & & & & \\
Other & 33 & $28(18.7)$ & $28(18.7)$ & 15.2 & $02.9-27.5$ & \\
\hline
\end{tabular}

Table [10]: Analysis of nature of work and perceived problems at work in persons with and without current psychiatric diagnosis

\begin{tabular}{|c|c|c|c|c|c|c|}
\hline Column $\Rightarrow 1$ & 2 & 3 & 4 & 5 & 6 & 7 \\
\hline Variable $\downarrow$ & $\begin{array}{c}\text { Total } \\
\mathrm{N}=235\end{array}$ & $\begin{array}{c}\text { Current } \\
\text { psychiatry } \\
\text { cases } \\
(\mathrm{N}=85) \\
\text { *except } \\
\mathrm{N}=70\end{array}$ & $\begin{array}{c}\text { No current } \\
\text { diagnosis } \\
\mathrm{N}=150 \\
\text { *except } \\
\mathrm{N}=104\end{array}$ & $\begin{array}{c}\text { Preva- } \\
\text { lence } \\
(\%)\end{array}$ & 95\% C.I. & $\begin{array}{l}\mathrm{X}^{2}, \mathrm{df}, \mathrm{P} \\
(\operatorname{col} 3 \mathrm{x} 4)\end{array}$ \\
\hline $\begin{array}{l}\text { Category of workers } \\
\text { according to the basic salary }\end{array}$ & & & & & & \\
\hline A category Rs.3,810-5,030 & 16 & $7(8.3)$ & $9(6.0)$ & 43.8 & $19.5-68.1$ & $x^{2}=5.051$ \\
\hline B category Rs.5,070-9,950 & 177 & $69(81.2)$ & $108(72.0)$ & 39.0 & $31.8-46.2$ & $\mathrm{df}=3$ \\
\hline C categoryRs.10,100-16,950 & 30 & $6(7.1$ & $24(16.0)$ & 20.0 & $15.5-24.5$ & $\mathrm{P}=0.168$ \\
\hline D categoryRs.17,200-27,050 & 12 & $3(3.5)$ & $9(6.0)$ & 33.3 & $02.5-64.1$ & \\
\hline $\begin{array}{l}\text { Shift } \\
A B C / A B\end{array}$ & 121 & $47(55.3)$ & $74(49.3)$ & 38.8 & $30.1-47.5$ & $\begin{array}{l}\mathrm{x}^{2}=0.772 \\
\mathrm{df}=1\end{array}$ \\
\hline GEN & 114 & $38(44.7)$ & $76(50.7)$ & 33.3 & $24.6-42.0$ & $P=0.380$ \\
\hline $\begin{array}{l}\text { Shift problems }(\mathrm{N}=174) \\
\text { Present }\end{array}$ & 116 & $* 48(68.6)$ & $* 68(65.4)$ & 41.4 & $32.4-50.4$ & $\begin{array}{l}x^{2}=0.191 \\
d f=1\end{array}$ \\
\hline Absent & 58 & $22(31.4)$ & $36(34.6)$ & 37.9 & $25.4-50.4$ & $P=0.662$ \\
\hline Interpersonal problems & 90 & $33(388)$ & $57(380)$ & 367 & $052-682$ & $\begin{array}{l}x^{2}=0.06 \\
d f=1\end{array}$ \\
\hline Absent & 145 & $52(61.2)$ & $93(62.0)$ & 35.9 & $28.1-43.7$ & $P=0.901$ \\
\hline Lob satisfaction & & & & & & $x^{2}=0.125$ \\
\hline Full satisfaction & 128 & $45(52.9)$ & $83(55.3)$ & 35.2 & $26.9-43.5$ & $\mathrm{df}=1$ \\
\hline Satisfied / NS & 107 & $40(47.1)$ & $67(44.7)$ & 37.4 & $28.2-46.6$ & $\mathrm{P}=0.723$ \\
\hline
\end{tabular}


Table [11]: Analysis of medical problems in persons with current psychiatric diagnosis in study small

\begin{tabular}{|l|c|c|c|c|c|l|}
\hline Column $\Rightarrow \mathbf{1}$ & 2 & 3 & 4 & 5 & 6 & \multicolumn{1}{c|}{7} \\
\hline Medical problems & $\begin{array}{c}\text { Frequencie } \\
\mathrm{s}(\mathrm{N}=235)\end{array}$ & $\begin{array}{c}\text { Current } \\
\text { psychiatry } \\
\text { cases } \\
(\mathrm{N}=85)\end{array}$ & $\begin{array}{c}\text { No current } \\
\text { diagnosis } \\
\mathrm{N}=150\end{array}$ & Prevalence & $95 \%$ C.I. & $\begin{array}{l}\mathrm{X}^{2} \text {, df, } \mathrm{P} \\
\text { (col 3x4) }\end{array}$ \\
\hline Present & 72 & $25(29.4)$ & $47(31.3)$ & 34.7 & $23.7-45.7$ & $\mathrm{X}^{2}=0.094$ \\
Absent & 163 & $60(70.6)$ & $103(68.7)$ & 36.8 & $29.4-44.2$ & $\begin{array}{l}\mathrm{df}=1 \\
\mathrm{p}=0.759\end{array}$ \\
\hline
\end{tabular}

Table [12]: Analysis of sociodemographic variables of responders and non responders of Occupational stress index questionnaire

\begin{tabular}{|c|c|c|c|c|}
\hline Variable & $\mathrm{N}=235$ & $\begin{array}{c}\text { Responders } \\
\mathrm{N}=185\end{array}$ & $\begin{array}{c}\text { Non responders } \\
\mathrm{N}=50\end{array}$ & $\mathrm{X}^{2}, \mathrm{df}, \mathrm{p}$ \\
\hline $\begin{array}{l}\text { Age } \\
21-30 \\
31-40 \\
41-50 \\
51-60 \\
\end{array}$ & $\begin{array}{r}10 \\
52 \\
122 \\
51\end{array}$ & $\begin{array}{c}9(4.9) \\
41(22.2) \\
88(47.6) \\
47(25.4)\end{array}$ & $\begin{array}{c}1(2) \\
11(22) \\
34(68) \\
4(8)\end{array}$ & $\begin{array}{l}X^{2}=9.420 \\
d f=3 \\
p=0.24\end{array}$ \\
\hline $\begin{array}{l}\text { Gender } \\
\text { Male } \\
\text { Female }\end{array}$ & $\begin{array}{c}225 \\
10 \\
\end{array}$ & $\begin{array}{c}176(95.1) \\
9(4.9)\end{array}$ & $\begin{array}{c}49(98) \\
1(2) \\
\end{array}$ & $\begin{array}{l}X^{2}=0.793 \\
d f=1 \\
p=0.373\end{array}$ \\
\hline $\begin{array}{l}\text { Religion } \\
\text { Hindu } \\
\text { Other religion }\end{array}$ & $\begin{array}{r}201 \\
34 \\
\end{array}$ & $\begin{array}{c}160(86.5) \\
25(13.5) \\
\end{array}$ & $\begin{array}{l}41(82) \\
9(18)\end{array}$ & $\begin{array}{l}X^{2}=0.640 \\
d f=1 \\
p=0.424\end{array}$ \\
\hline $\begin{array}{l}\text { State } \\
\text { Karnataka } \\
\text { Other states }\end{array}$ & $\begin{array}{r}203 \\
32\end{array}$ & $\begin{array}{c}156(84.3) \\
29(15.7)\end{array}$ & $\begin{array}{c}47(94) \\
3(6)\end{array}$ & $\begin{array}{l}X^{2}=3.133 \\
d f=1 \\
p=0.077\end{array}$ \\
\hline $\begin{array}{l}\text { Marital Status } \\
\text { Married } \\
\text { Unmarried }\end{array}$ & $\begin{array}{r}226 \\
9 \\
\end{array}$ & $\begin{array}{c}178(96.2) \\
7(3.8) \\
\end{array}$ & $\begin{array}{c}48(94) \\
2(4) \\
\end{array}$ & $\begin{array}{l}X^{2}=0.005 \\
d f=1 \\
p=0.944\end{array}$ \\
\hline $\begin{array}{l}\text { Education } \\
<12^{\text {th }} \text { standard } \\
\text { ITI/ Diploma/ } \\
\text { BE } \\
\text { Other }\end{array}$ & $\begin{array}{r}83 \\
119 \\
\\
33\end{array}$ & $\begin{array}{c}67(36.2 \\
91(49.1) \\
27(14.6)\end{array}$ & $\begin{array}{l}16(32) \\
28(56) \\
6(12)\end{array}$ & $\begin{array}{l}X^{2}=0.747 \\
d f=2 \\
p=0.688\end{array}$ \\
\hline
\end{tabular}


Table [13]: Analysis of nature of work and perceived problems at work in responders and non responders of occupational stress index questionnaire

\begin{tabular}{|c|c|c|c|c|}
\hline Variable & $\mathrm{N}=235$ & $\begin{array}{c}\text { Responders } \\
\mathrm{N}=185 \\
\text { Except } \\
\mathrm{N}=136\end{array}$ & $\begin{array}{l}\text { Nonresponders } \\
\quad \mathrm{N}=50 \\
\text { *except } \mathrm{n}=38\end{array}$ & $\begin{array}{l}\mathrm{X}^{2}, \mathrm{df}, \mathrm{P}(\mathrm{col} \\
3 \mathrm{x} 4)\end{array}$ \\
\hline \multicolumn{5}{|l|}{$\begin{array}{l}\text { Category of workers according } \\
\text { to the basic salary }\end{array}$} \\
\hline A category Rs.3,810-5,030 & 16 & $13(7.0)$ & $3(6)$ & $x^{2}=14.355$ \\
\hline B category Rs.5,070-9,950 & 177 & $130(70.3)$ & $47(94)$ & $\mathrm{df}=3$ \\
\hline C category Rs.10,100-16,950 & 30 & $30(16.2)$ & - & $\mathrm{P}=0.002$ \\
\hline D category Rs.17,200-27,050 & 12 & $12(6.5)$ & - & \\
\hline Shift & & & & $x^{2}=1.842$ \\
\hline$\overline{\mathrm{ABC}} / \mathrm{AB}$ & 121 & $91(49.2)$ & $30(60)$ & $\mathrm{df}=1$ \\
\hline GEN & 114 & $94(50.8)$ & $20(40)$ & $\mathrm{P}=0.175$ \\
\hline Shift problems $(\mathrm{N}=174)$ & & & & $x^{2}=0.269$ \\
\hline Present & 116 & *92(67.6) & $* 24(63.2)$ & $\mathrm{df}=1$ \\
\hline Absent & 58 & $44(32.4)$ & $14(36.8)$ & $\mathrm{P}=0.604$ \\
\hline Interpersonal problems & & & & $x^{2}=0.002$ \\
\hline Present & 90 & $71(38.4)$ & $19(38)$ & $\mathrm{df}=1$ \\
\hline Absent & 145 & $114(61.6)$ & $31(62)$ & $\mathrm{P}=0.961$ \\
\hline Job satisfaction & & & & $\mathrm{x}^{2}=0.319$ \\
\hline Full satisfaction & 128 & $99(53.5)$ & $29(58)$ & $\mathrm{df}=1$ \\
\hline Satisfied / NS & 107 & $86(46.5)$ & $21(42)$ & $\mathrm{P}=0.572$ \\
\hline
\end{tabular}

Table [14]: Analysis of physical problem in responders and non responders of occupational stress index questionnaire

\begin{tabular}{|l|c|c|c|l|}
\hline Variable & $\mathrm{N}=235$ & $\begin{array}{c}\text { Responders } \\
\mathrm{N}=185\end{array}$ & $\begin{array}{c}\text { Nonresponders } \\
\mathrm{N}=50\end{array}$ & $\mathrm{X}$, df, $\mathrm{P}$ \\
\cline { 1 - 4 } Present & 72 & $59(31.9)$ & $13(26)$ & $\begin{array}{l}\mathrm{X}^{2}=0.643 \\
\mathrm{df}=1 \\
\mathrm{p}=0.423\end{array}$ \\
\hline Absent & 163 & $126(68.1)$ & $37(74)$ & \\
\hline
\end{tabular}

